\title{
Some Predictors of Cardiovascular Mortality Among the Elderly Population of Botucatu (SP)
}

\author{
Tania Ruiz, Mirela D. Sanchís, Ana Maria Fioravante, Xavier C. Piqué \\ Botucatu, SP - Barcelona, Espanha
}

\begin{abstract}
Objective - To detect factors associated with cardiovascular mortality in the elderly of Botucatu.

Methods - We evaluated 29 variables of interest in a cohort of patients aged ${ }^{3} 60$ using data from a survey conducted between 1983/84. The elderly cohort was analyzed in 1992 to detect the occurrence of cardiovascular deaths. Survival analysis was performed using the Kaplan-Meier method, the log-rank test, and Cox regression analysis. Three models were adapted for each group of variables, and a final model was chosen from those variables selected from each group.
\end{abstract}

Results - We identified predictor for cardiovascular death according to age for elderly males not supporting the family, not possessing a vehicle, and previous cardiovascular disease. In elderly females, the predictor variables were previous cardiovascular disease and diabetes mellitus.

Conclusion -Socioeconomic indicators (family heading and vehicle ownerrship) may be added to well stabilished medical factors (diabete mellitus and hypertension to select target groups for programs intended to reduce deaths due to cardiovascular diseases in elderly people.

Key words: survival, cardiovascular disease, elderly

Faculdade de Medicina de Botucatu - UNESP e Institut Català d' Oncologia, Barcelona

Mailing address: Tania Ruiz - Department of Public Health - Faculdade de Medicina de Botucatu (UNESP) - Caixa postal, 970 - 18618-970 - Botucatu, SP - E-mail: truiz@fmb.unesp.br
The aging of the population, an incontestable fact of Brazilian demography in the last decades ${ }^{1,2}$, has made the study of the elderly of utmost importance, because few data are available for the social planning of the population, within this new profile that emerges in this century.

Mortality records are important sources of information about social health, although in developing countries, Brazil among them, problems exist regarding the reliability of the causes reported in death certificates, which needs to be constantly remembered ${ }^{3,4}$.

Cardiovascular diseases are the most frequent cause of mortality in the elderly ${ }^{5}$, and, of them, ischemic heart disease and cerebrovascular disease stand out ${ }^{6,7}$. The importance of mortality from cardiovascular causes in the elderly increases as we observe that, besides the high incidence of death from these diseases being reported at baseline in death certificates, Brazilian elderly have an average of $3.6 \%$ diagnoses reported on the certificates, and cardiovascular diseases make up $65 \%$ of these diagnoses ${ }^{7,8}$.

Regarding the known risk factors of mortality in the elderly, gender is the most studied mortality risk, because a greater survival in females is detected in almost all American, Asian, and European countries ${ }^{9}$. Gender is not properly a risk factor, but mortality has a different behavior in each gender, and, therefore, a separate analysis is more appropriate.

Risk factors for cardiovascular diseases in the elderly frequently reported in the literature are blood cholesterol levels ${ }^{10-12}$ and systolic blood pressure, and less significantly, diastolic blood pressure ${ }^{13-18}$, body mass index ${ }^{19}$, smoking ${ }^{12}$, diabetes mellitus ${ }^{20}$, social class ${ }^{21}$, marital status ${ }^{14,22}$, and social support to the elderly ${ }^{23}$.

The presence of these risk factors in Brazil is high; therefore, the possibility of intervention is considerable and important, especially if we compare the decrease in mortality from cardiovascular disease in Brazil and other countries in the last few years and conclude that we can achieve an even greater decrease in cardiovascular mortality. 


\section{Methods}

In 1983 and 1984, we implemented a questionnaire of the aforesaid mortality in Botucatu city. The population of the town was, at that time, 64,476 inhabitants, of which $5,853(9.1 \%)$ were over 60 . We considered the whole urban population, 58,251 inhabitants as the universe of the general inquiry. The sample was conducted in two stages. The first stage consisted of analyzing sections of the census, which were proportionally represented according to social status, defined by housing characteristics, and the extent of urbanization in different areas. In the second stage, houses were randomly sampled ${ }^{24}$ within the groups of stratified sectors with respect to the proportionality of the population. The sample had 16 census sections, 1,769 houses, and 7,075 individuals. In this sample, 640 people were 60 or over at that time and constituted the cohort of the present survival study.

Data assessment concerning the blood pressure evaluation of the 60 or older population was performed 3 months after the beginning of questionnaire implementation to obtain the other information related to the survey. Because of the time delay, some individuals were not found when blood pressure evaluation was carried out because of address changes, temporary absence, refusals, and so forth. For the purpose of evaluating whether those absences produced bias in the sample, the frequency of all variables obtained in the first stage of the questionnaire (which collected social data such as documented morbidity and accidents) and in the second stage (when blood pressure evaluation was performed) were compared using the chi-square test. The results obtained showed that most variables, including all the demographic variables, did not reveal different behaviors in either population. We have chosen, therefore, to include some of the variables from the pressoric evaluation.

Members of the cohort, which comprised 640 elderly who were 60 or over, were contacted again in 1992 . We assessed 574 elderly (89.6\%). Initially, we tried to contact the respondents to the questionnaire at the address provided in 1983/84. In the case of change in the address, the neighbors were asked about the whereabouts of the participants. We have also looked for them in the phone book, in the city's Institution for the elderly, in the records of the Hospital das Clínicas or of the Centro de Saúde-Escola (Clinicas Hospital and Health-School Center), and also in the records of retired people receiving Social Security in Botucatu. Information regarding the date of death came from the death certificate and was confirmed afterwards either by locating this information at the Seção de Vigilância Epidemiológica do Centro de Saúde-Escola (Section of Epidemics Surveillance of the Health-School Center) where photocopies of all death certificates of the town are kept or in death records obtained from the notary's office of Botucatu from 1983 until that time. Individuals not found and whose death certificates were not located either were considered lost. At the end of this procedure, 574 elderly had been found $(89.6 \%$ of the initial cohort) and formed the cohort of the present study.
Variables studied as risk factors for death from cardiovascular disease were the following: variables considered as socioeconomic: age (60 to 69 years - 70 years or over), color (whites - nonwhites), economically active (yes - no), wage ( 3 or more minimum wage - 1 or more - and less than 3 minimum wage-less than 1 minimum wage), per capita income ( 1 or more minimum wage $-1 / 2$ or more-and less than 1 minimum wage - less than $1 / 2$ minimum wage), other incomes (yes - no), retired (yes - no), education (elementary school, elementary school unfinished, literate), has a vehicle (yes no), has a telephone (yes - no), origin (Botucatu, other town; urban area, other city; rural area), length of time living in the town (15 years or over, less than 15 years), number of people in the house ( 1 or 2, 3 or 4, 5 or more), type of residence (own or rented, other possibilities); variables related to family: married (yes - no), support the family (himself or spouse other relatives), family income ( 5 or more minimum wage -3 or more and less than 5 minimum wage - up to 3 minimum wage), number of generations in the house (1 - 2 - 3 , or more); variables related to morbidity: circulatory system diseases, respiratory system diseases, hypertensive diseases, diabetes mellitus, neoplasia, musculoskeletal diseases, chronic diseases, and presence of hypertensive people in the family (no - yes); measured: average of 3 measures of systolic blood pressure $(136 \mathrm{mmHg}$ or lower - higher than $136 \mathrm{mmHg})$ and diastolic $(100 \mathrm{mmHg}$ or lower - higher than $100 \mathrm{mmHg}$ ) performed during domicile calls and the Quetelet index (calculated from the measures of weight and height of each elderly).

Variables studied were stratified according to percentiles of distribution and, in some cases, by segments previously tested in other studies. When the variable could not be divided into strata naturally and it was difficult to stratify according to percentiles, survival curves estimated through the Kaplan-Meier ${ }^{25}$ method helped to adjust the stratification intervals.

Obtained data were analyzed using survival analysis techniques and death from cardiovascular disease was considered the "event". Individuals who died were considered as censored because it was impossible to know how long that patient would survive with cardiovascular disease, the event of our interest. We considered all the diseases included in codes 390.0 to 459.0 of the International Classification of Diseases 9 th revision ${ }^{26}$ as cardiovascular diseases.

For the performance of a preliminary exploratory analysis, the Kaplan-Meier estimate and log-rank test were used, applied to each independent risk factor. The association between the variables studied as risk factors was also evaluated through the chi-square and Fisher's exact tests applied to frequency tables.

To evaluate the effect of each risk factor when controlled by other risks, we used the $\mathrm{Cox}^{27}$ regression model. The presupposition of this proportional hazard model between different strata of each variable was detected through the graphic $\log [-\log \hat{S}(t)]$ versus $\log (t)$, based on estimated data of Kaplan-Meier to survival function $S(t)$, for each variable. 
To perform the adjustment of the model, 3 blocks of variables were considered: socioeconomic strata, variables related to the family, and morbidity, taking into account the multiple regression model according to the relationship between the studied variables considered as risk factors and the time that cardiovascular death had occurred.

To perform the adjustment of the models, variables in which proportionality of the risks was not verified, according to the analysis of the graphic mentioned above, and the nonsignificant difference between the survival curves ( $p>0.05$ ) according to log-rank test were discharged. For each model, the selection of the variables was in accordance with the procedure described by Collett ${ }^{28}$, based on the variables with proportional risks and significant differences between survival curves $(\mathrm{p}<0.05)$ and considering afterwards, the variables with proportional risks and nonsignificant differences between the survival curves. The variable age was included in all models so that the effects of the other variables would not be confused with the effects of that one.

Once the models were adjusted to the 3 blocks of variables, we started with the model of the socioeconomic variables, including the variables related to the families selected in the corresponding model. In the resulting model, we kept only the statistically significant variables $(\mathrm{p}<0.05)$. Then, the morbidity variables selected were included in the model keeping, once more, only the variables whose effect was significant in the resulting model, obtaining thus, the final model.

Analysis was carried out separately for each gender, because men and women have very different behaviors with regard to survival.

Statistics programs used were SPSS and SAS.

\section{Results}

We evaluated 266 men and 308 women. The mean age of this population was very similar in both sexes: 68.5 years for men, with a standard error of 7.7 years, and 68.7 years for women, with a standard error of 7.0 years. After the observation period, $34.8 \%$ of participants $(n=200)$ had passed away, that i.e., $59.5 \%(\mathrm{n}=119)$ from cardiovascular disease. In the female patients, 99 deaths occurred, and $58.7 \%$ were caused by cardiovascular disease. In the male patients, of the 101 deaths, $60.4 \%$ were caused by cardiovascular disease (table I).

Regarding the profile of the elderly from Botucatu in $1983 / 84$, more than half were aged around 60 to 69 years, most of them were married white men and widowed women who had lived in the town for over 30 years. In regard to the standard of living, they lived in their own house, either already paid for or still being paid for, with 1 or 2 generations living in the house, and either the participant or spouse supporting the family. They possessed neither a car nor a telephone. The men were retired (71.7\%), and the women declared themselves pensioners $(34.1 \%)$ or housewives $(36.0 \%)$. The elderly had poor education and low income (tab. II).

Concerning health, $69.7 \%$ of the elderly reported some kind of chronic disease (that had been present for over a

\begin{tabular}{|c|c|c|c|c|c|c|}
\hline \multirow{2}{*}{ Variables } & \multicolumn{2}{|c|}{ Men } & \multicolumn{2}{|c|}{ Women } & \multicolumn{2}{|c|}{ Total } \\
\hline & $\mathrm{n}^{\mathrm{o}}$ & $(\%)$ & $\mathrm{n}^{\circ}$ & $(\%)$ & & $(\%)$ \\
\hline Alive at the end of the study & 165 & $(62.0)$ & 209 & $(67.9)$ & 374 & $(65.2)$ \\
\hline Dead at th & 101 & $(38$ & 99 & $(32$ & 200 & \\
\hline Deaths from CVD (390.0-459.9) & 61 & (60.4) & 58 & (58.6) & 119 & (59.5) \\
\hline Ischemic disease (410.0-414.9) & 27 & (26.7) & 29 & (29.3) & 56 & (28.0) \\
\hline Cerebrovascular (430.0-438.9) & 23 & (22.8) & 13 & (13.1) & 36 & (18.0) \\
\hline Other heart diseases & 11 & (10.9) & 16 & $(16.2)$ & 27 & (13.5) \\
\hline
\end{tabular}

year); $36.9 \%$ reported some kind of circulatory system disease, and $23.7 \%$ reported hypertension and $6.6 \%$ diabetes mellitus (tab. III).

According to the log-rank test, both for females and males, a significant difference $(\mathrm{p}<0.01)$ existed between the survival curves estimated for both age groups considered (60 to 69 years and 70 years or older). In both sex, as we had

\begin{tabular}{|c|c|c|c|c|c|}
\hline \multicolumn{6}{|c|}{$\begin{array}{l}\text { Table II - Description of a cohort of elderly of } 60 \text { or older, } \\
\text { according to sex. Botucatu (SP), 1983/84 - } 1992\end{array}$} \\
\hline \multirow[t]{2}{*}{ Variables } & \multicolumn{2}{|c|}{ Men } & \multicolumn{2}{|c|}{ Women } & Total \\
\hline & $\mathrm{n}^{\circ}$ & $(\%)$ & $\mathrm{n}^{\circ}$ & $(\%)$ & $\mathrm{n}^{\circ} \quad(\%)$ \\
\hline \multicolumn{6}{|l|}{ Age } \\
\hline $60-69$ years & 176 & $(66.2)$ & 179 & $(58.1)$ & $355(61.8)$ \\
\hline 70 years or older & 90 & $(33.8)$ & 129 & (41.9) & $219(38.2)$ \\
\hline \multicolumn{6}{|l|}{ Color } \\
\hline White & 239 & $(89.8)$ & 273 & $(88.6)$ & $512(89.2)$ \\
\hline Nonwhite & 27 & $(10.2)$ & 35 & (11.4) & $62(10.8)$ \\
\hline \multicolumn{6}{|l|}{ How long has lived in town } \\
\hline Up to 15 years & 52 & $(19.5)$ & 57 & (19.5) & $109(19.0)$ \\
\hline 15 or over & 214 & $(80.4)$ & 251 & $(81.5)$ & $465(81.0)$ \\
\hline \multicolumn{6}{|l|}{ Marital status } \\
\hline Married & 225 & $(84.6)$ & 133 & $(43.2)$ & $358(62.4)$ \\
\hline Unmarried & 41 & $(15.4)$ & 175 & $(56.8)$ & $216(37.6)$ \\
\hline \multicolumn{6}{|c|}{ Number of generations living in the house } \\
\hline Only one generation & 91 & 34.2 & 110 & 35.7 & 20135.0 \\
\hline Two generations & 103 & 38.7 & 103 & 33.4 & 20635.9 \\
\hline Three or more & 72 & 27.1 & 95 & 30.8 & $167 \quad 29.1$ \\
\hline \multicolumn{6}{|c|}{ Support the family or spouse } \\
\hline Yes & 249 & 93.6 & 249 & 80.8 & $498 \quad 86.7$ \\
\hline No & 17 & 6.4 & 59 & 19.2 & $76 \quad 13.3$ \\
\hline \multicolumn{6}{|l|}{ Education } \\
\hline \multicolumn{6}{|l|}{ Primary unfinished or } \\
\hline literat & 120 & $(45.1)$ & 112 & $(36.4)$ & $232(40.1)$ \\
\hline No: illiterate & 39 & $(14.7)$ & 116 & $(37.6)$ & $155(27.0)$ \\
\hline \multicolumn{6}{|l|}{ Income } \\
\hline One salary or overs & 135 & $(50.8)$ & 139 & $(45.1)$ & $274(47.7)$ \\
\hline Half or one minimum salary & 80 & $(30.1)$ & 107 & $(34.7)$ & $187(32.6)$ \\
\hline Up to half minimum salary & 49 & $(18.4)$ & 57 & $(18.5)$ & $106(18.5)$ \\
\hline No information & 2 & $(0.8)$ & 5 & $(1.6)$ & $7 \quad(0.01)$ \\
\hline \multicolumn{6}{|l|}{ “Other incomes" } \\
\hline Have other incomes & 70 & $(26.3)$ & 42 & (13.6) & $109(18.9)$ \\
\hline Don't have other incomes & 186 & $(69.9)$ & 266 & $(86.4)$ & $451(78.6)$ \\
\hline No information & 10 & $(3.7)$ & 4 & $(1.3)$ & $14 \quad(2.4)$ \\
\hline \multicolumn{6}{|l|}{ Possess a vehicle } \\
\hline Yes & 101 & $(38.0)$ & 95 & $(30.8)$ & $196(34.2)$ \\
\hline No & 165 & $(62.0)$ & 213 & $(69.2)$ & $378(65.8)$ \\
\hline
\end{tabular}


expected, the age group that had a higher risk for death from cardiovascular disease was 70 or older group.

Mean lifetime of females was 8 years, 7 months and 27 days for the age group of 60 to 69 years and of 6 years, 7 months and 7 days for the age group of 70 years or older. In males, this time was 7 years, 10 months and 27 days for the age group of 60 to 69 years and of 6 years, 10 months and 15 days for the age group of 70 years or over.

Tables IV through VII present the results of the logrank test for some variables, with the population stratified by age group. Through the analysis of these tables, we can observe the effect of age in the survival curves of the population and also the misleading effect of other variables that were not significant in the Cox model.

In the proportionality study of risks among the several strata of each variable, for males, the variables that had proportional risks and significant differences $(p<0.05)$ between the survival curves of their different stratum were: age, wage, other income, retirement, having a vehicle, possessing or not their own house, supporting the family, circulatory system disease, hypertensive disease, the presence of malignancies, and average of systolic pressure measure. The variables that indicated proportional risks and nonsignificant differences ( $p>0.05)$ between the survival curves were: presence of respiratory system disease, musculoskeletal diseases, diabetes, average of diastolic pressure, and the Quetelet index. For females, the variables that indicated proportional risks and significant differences among the survival curves of their different stratum were: being married, supporting the family, presence of circulatory system disease and diabetes. The variables that had proportional risks and nonsignificant differences between the survival curves were: retirement, other income, and presence of chronic diseases and of hypertensive disease.

\begin{tabular}{|c|c|c|c|}
\hline \multicolumn{4}{|c|}{$\begin{array}{l}\text { Table III - Morbidity in cohort of elderly of } 60 \text { years or over, } \\
\text { according to sex. Botucatu (SP), 1983/84 - } 1992\end{array}$} \\
\hline Variables & $\begin{array}{c}\text { Men } \\
\mathbf{n}(\%)\end{array}$ & $\begin{array}{l}\text { Women } \\
\text { n }(\%)\end{array}$ & $\begin{array}{c}\text { Total } \\
\mathbf{n}(\%)\end{array}$ \\
\hline \multicolumn{4}{|c|}{ Mean diastolic pressure } \\
\hline$\leq 100 \mathrm{mmHG}$ & $163(61.3)$ & $213(69.2)$ & $376(65.5)$ \\
\hline$>100 \mathrm{mmHG}$ & $26(9.8)$ & $39(12.7)$ & $65(11.3)$ \\
\hline No information & $77(28.9)$ & $56(18.2)$ & $133(23.2)$ \\
\hline \multicolumn{4}{|c|}{ Mean systolic pressure } \\
\hline$\leq 136 \mathrm{mmHG}$ & $76(28.6)$ & $65(21.1)$ & $141(24.6)$ \\
\hline$>136 \mathrm{mmHG}$ & $113(42.5)$ & $187(60.7)$ & $300(52.2)$ \\
\hline No information & $77(28.9)$ & $56(18.2)$ & $133(23.2)$ \\
\hline \multicolumn{4}{|c|}{ Reference to cardiovascular disease } \\
\hline Yes & $75(28.2)$ & $137(44.5)$ & $212(36.9)$ \\
\hline No & $191(71.8)$ & $171(55.5)$ & $362(63.1)$ \\
\hline \multicolumn{4}{|c|}{ Reference to hypertension } \\
\hline Yes & $43(16.2)$ & $93(30.2)$ & $136(23.7)$ \\
\hline No & $223(83.8)$ & $215(69.8)$ & $438(76.3)$ \\
\hline \multicolumn{4}{|c|}{ Reference to chronic disease } \\
\hline Yes & $164(61.7)$ & $236(76.6)$ & $400(69.7)$ \\
\hline No & $102(38.3)$ & $72(23.4)$ & $174(30.3)$ \\
\hline \multicolumn{4}{|c|}{ Reference to diabetes mellitus } \\
\hline Yes & $11(4.1)$ & $27(8.8)$ & $38(6.6)$ \\
\hline No & $255(95.9)$ & $281(91.2)$ & $536(93.4)$ \\
\hline
\end{tabular}

\begin{tabular}{|c|c|c|c|c|c|c|}
\hline \multicolumn{7}{|c|}{$\begin{array}{c}\text { Table IV - Size of the sample (s), number of deaths (d) and the result } \\
\text { of log-rank test to compare survival curves to cardiovascular diseases } \\
\text { estimated by the Kaplan-Meier method by variable and by age, } \\
\text { obtained in a cohort of elderly male of } 60 \text { or older, in the end of the } \\
\text { period studied 1983-1992, Botucatu (SP) }\end{array}$} \\
\hline \multirow[b]{2}{*}{ Variable } & \multicolumn{2}{|c|}{ 60-69 years } & \multicolumn{4}{|c|}{70 years or older } \\
\hline & $\mathrm{n}$ & d & $\begin{array}{l}\text { Log-rank } \\
\text { p value }\end{array}$ & $\mathrm{n}$ & $\mathrm{d}$ & $\begin{array}{c}\text { Log-rank } \\
\text { p value }\end{array}$ \\
\hline \multicolumn{7}{|l|}{ Color } \\
\hline White & 157 & 22 & 0.04 & 82 & 27 & 0.00 \\
\hline Nonwhite & 19 & 6 & & 8 & 6 & \\
\hline \multicolumn{7}{|l|}{ How long is in town } \\
\hline 15 years or over & 142 & 24 & 0.52 & 72 & 23 & 0.07 \\
\hline Less than 15 years & 34 & 4 & & 18 & 10 & \\
\hline \multicolumn{7}{|l|}{ Possess a vehicle } \\
\hline Yes & 73 & 6 & 0.01 & 28 & 7 & 0.26 \\
\hline No & 103 & 22 & & 62 & 26 & \\
\hline \multicolumn{7}{|l|}{ Other incomes } \\
\hline Yes & 47 & 3 & 0.02 & 23 & 8 & 0.47 \\
\hline No & 121 & 25 & & 65 & 25 & \\
\hline \multicolumn{7}{|l|}{ Supports the family } \\
\hline Yes & 170 & 26 & 0.24 & 79 & 28 & 0.16 \\
\hline No & 6 & 2 & & 11 & 5 & \\
\hline \multicolumn{7}{|c|}{ Type of possession of real state of living } \\
\hline $\begin{array}{l}\text { Own, paying for it } \\
\text { or rented }\end{array}$ & 165 & 24 & 0.01 & 80 & 29 & 0.75 \\
\hline Given or lent & 11 & 4 & & 10 & 4 & \\
\hline
\end{tabular}

\begin{tabular}{|c|c|c|c|c|c|}
\hline \multicolumn{6}{|c|}{$\begin{array}{l}\text { Table V - Size of the sample (n), number of deaths (d) and log-rank test } \\
\text { result for comparison of survival curves to cardiovascular diseases } \\
\text { estimated by Kaplan-Meier method, by variable and by age group } \\
\text { obtained in a cohort of male elderly who were } 60 \text { or over, in the end of } \\
\text { the studied period, 1983-1992, Botucatu (SP) }\end{array}$} \\
\hline \multirow[b]{2}{*}{ Variable } & \multicolumn{2}{|c|}{ 60-69 years } & \multicolumn{3}{|c|}{70 years or over } \\
\hline & $\mathrm{n}$ & $\mathrm{d}$ & $\begin{array}{c}\text { Log-rank } \\
\text { p value }\end{array}$ & $\mathrm{n} \quad \mathrm{d}$ & $\begin{array}{c}\text { Log-rank } \\
\text { p value }\end{array}$ \\
\hline \multicolumn{6}{|c|}{ Mean diastolic pressure } \\
\hline$\leq 100 \mathrm{mmHG}$ & 104 & 14 & 0.45 & 5918 & 0.34 \\
\hline$>100 \mathrm{mmHG}$ & 19 & 4 & & 73 & \\
\hline \multicolumn{6}{|c|}{ Mean systolic pressure } \\
\hline$\leq 136 \mathrm{mmHG}$ & 62 & 5 & 0.03 & 144 & 0.89 \\
\hline$>136 \mathrm{~mm} \mathrm{Hg}$ & 61 & 13 & & 5217 & \\
\hline \multicolumn{6}{|c|}{ Reference to diabetes mellitus } \\
\hline $\operatorname{Sim}$ & 5 & 1 & 0.72 & & 0.97 \\
\hline Não & 171 & 27 & & 8432 & \\
\hline \multicolumn{6}{|c|}{ Reference to cardiovascular disease } \\
\hline Sim & 48 & 13 & 0.00 & 6323 & 0.94 \\
\hline Não & 128 & 15 & & 2710 & \\
\hline \multicolumn{6}{|c|}{ Reference to hypertension } \\
\hline Sim & 29 & 9 & 0.00 & 145 & 0.89 \\
\hline Não & 147 & 19 & & $76 \quad 28$ & \\
\hline
\end{tabular}

Using the methodology described and using a hierarchical study of the variables in the Cox model, the variables that were predictors of death from cardiovascular disease in this study, adjusted for age, in males were: possessing a vehicle, supporting the family, and the presence of circulatory system disease, and in females they were: the presence of circulatory system disease and diabetes.

The results of the adjustment of the Cox regression 
Tabela VI - Tamanho da amostra (n), número de mortes (d) e resultado do teste log-rank para comparação de curvas de sobrevivência a doenças cardiovasculares estimada pelo método de KaplanMeier por variável e por faixa etária, obtidos para uma coorte de idosos femininos de 60 anos ou mais, no final do período estudado 1983-1992, Botucatu (SP)

\begin{tabular}{|lccccccc|}
\hline & 60-69 anos & \multicolumn{5}{c|}{ 70 anos ou mais } \\
Variável & $\mathrm{n}$ & $\mathrm{d}$ & $\begin{array}{c}\text { Log-rank } \\
\text { valor de } \mathrm{p}\end{array}$ & $\mathrm{n}$ & $\mathrm{d}$ & $\begin{array}{c}\text { Log-rank } \\
\text { valor de } \mathrm{p}\end{array}$ \\
& & & & & & & \\
Cor & & & & & & \\
Brancos & 153 & 11 & 0.52 & 120 & 40 & 0.25 \\
Não brancos & 26 & 3 & & 9 & 4 & \\
Tempo no município & & & & & & \\
15 anos ou mais & 148 & 14 & 0.08 & 103 & 39 & 0.051 \\
Menos de 15 anos & 31 & 0 & & 26 & 5 & \\
Propriedade de automóvel & & & & & & \\
Sim & 57 & 3 & 0.39 & 38 & 11 & 0.57 \\
Não & 122 & 11 & & 91 & 33 & \\
Outras rendas & & & & & & \\
Sim & 19 & 1 & 0.58 & 23 & 6 & 0.20 \\
Não & 160 & 13 & & 106 & 38 & \\
\hline
\end{tabular}

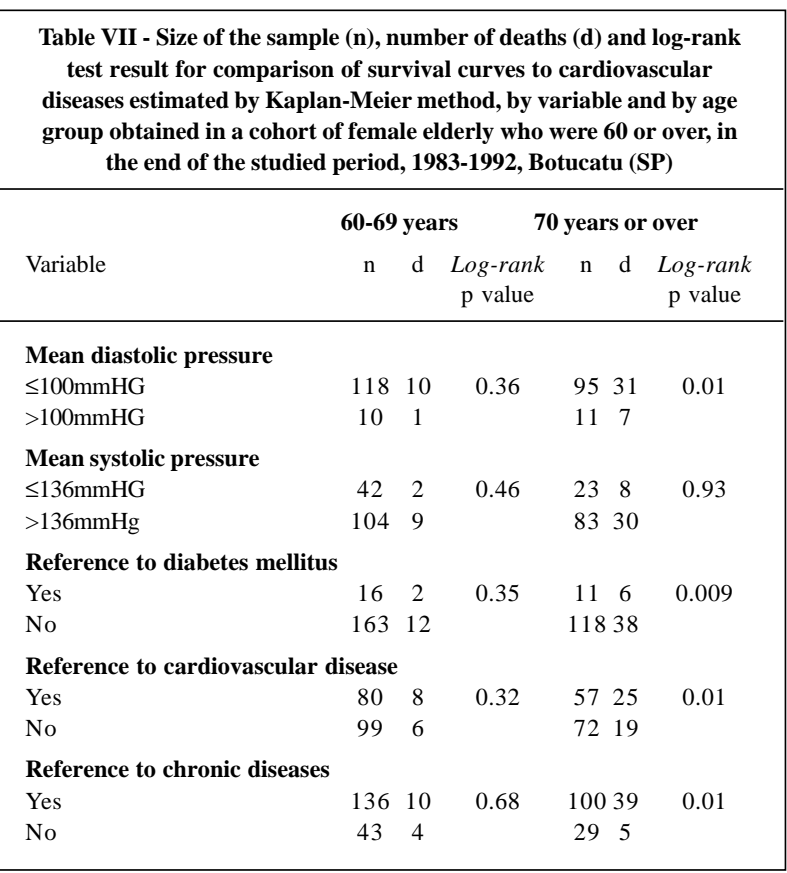

model performed for males and females with the respective reasons for risks are found in tables VIII and IX.

\section{Discussion}

The most important variable described in this study, which identifies those groups of elderly people in the town of Botucatu who are at risk for death from cardiac diseases, is previous cardiovascular disease in those patients. Hypertension, which is always mentioned in the literature ${ }^{2,13-17}$, as assessed by statistical analysis was present (log-rank test) and found to be a risk factor and is represented by the variables: averages of systolic and diastolic pressure measu- res, family history of hypertension, and disease of the circulatory system. For females, concerning morbidity, diabetes was another important risk described.

Regarding the socioeconomic variables, the elderly of Botucatu were generally retired, with a low fixed pension. For this reason, income was neither a good social indicator nor a risk, as formal income did not discriminate among the elderly. The Cox model revealed that having a car or supporting the family for the male gender was a discriminating social variable. Concerning females, no significant socioeconomic variable existed as a risk factor related to cardiovascular death; therefore, we conclude that the elderly in Botucatu are very homogeneous regarding their standard of life; most of them have a poor socioeconomic standard, that is, living for many years in a quiet city, not very large, in their own house, and with a low income.

The fact that husbands answered the interviews for the females may explain the pattern of the social variables regarding mortality in the elderly population of Botucatu. Therefore, it was impossible to evaluate socioeconomic risks for the female population. Concerning the male gender, two variables, possessing a car or supporting the family, persisted until the final model as a risk factor for cardiovascular death in man, which may reflect only the amount of money earned, because the information regarding who supported the family can concur with the one who earns more money. The same can be said about having a car.

It is also important to take into account in this discussion the structure of the city's public health services. The city has a reasonable public health service, when compared with the national average, two acceptable hospitals for medium procedures and a medical school hospital where most of the patients are from Botucatu.

\begin{tabular}{|c|c|}
\hline \multicolumn{2}{|c|}{$\begin{array}{l}\text { Table VIII - Results of the Cox regression model adjustment to } \\
\text { the data of survival to cardiovascular disease in a cohort of male } \\
\text { elderly ( } 60 \text { years or over). Botucatu (SP), 1983-1992 }\end{array}$} \\
\hline Variable & $\begin{array}{c}\text { Odds ratio } \\
\text { (confidence interval - 95\%) }\end{array}$ \\
\hline Age ( 70 years or over/60-69 years) & $2.65(1.58-4.48)$ \\
\hline Supports the family (no/yes) & $2.84 \quad(1.23-6.58)$ \\
\hline Possess a vehicle (no/yes) & $2.36(1.27-4.50)$ \\
\hline $\begin{array}{l}\text { Reference to circulatory } \\
\text { system disease (yes/no) }\end{array}$ & $1.91(1.14-3.37)$ \\
\hline
\end{tabular}

\begin{tabular}{|l|l|}
\hline $\begin{array}{l}\text { Table IX - Results of the Cox regression model adjustment to the } \\
\text { data of survival to cardiovascular disease in a cohort of female } \\
\text { elderly (60 years or over). Botucatu (SP), 1983-1992 }\end{array}$ \\
\hline $\begin{array}{l}\text { Variable } \\
\text { Odds ratio } \\
\text { (confidence interval - 95\%) }\end{array}$ \\
$\begin{array}{l}\text { Age (70 years or over/60-69 years) } \\
\text { Reference to circulatory }\end{array}$ \\
$\begin{array}{l}\text { system disease (yes/no) } \\
\text { Reference to diabetes mellitus (yes/no) }\end{array}$ & 2.59 (1.56 - 12.0) \\
\hline
\end{tabular}


In addition, it is important to emphasize that these were the variables that were reported in this study as risk factors for cardiovascular death. Other important variables reported in the literature, such as cholesterol, family history, body mass index, and smoking ${ }^{10-18}$, were not investigated because we had no data in the 1983/84 study.

Another bias in the results was the errors in death certificates, which is not insignificant in third world countries, and of which we do not have an exact count.

Therefore, risk factors considered important for cardiovascular death were hypertension for men, and, for females, diabetes mellitus.

To conclude with, in Brazil's Sistema Único de Saúde (Single Health System) attention is paid to the elderly in the Programa de Saúde do Adulto (Adult Health Program), focusing on diabetes and hypertension.

Based on the results achieved, we recommend that this program is maintained in the short- and mid-term, especially in regards to prevention, which would be the intervention recommended to the town, with the purpose of decreasing death rates due to cardiovascular diseases in this age group. The selection of social risk groups would be effective with the aim proposed through family supporting and possessing a car.

\section{Acknowledgements}

The authors wish to thank the Fundación Mapfre Medicina (Espanha), Dr. Xavier Bosch (Servei d"Epidemiologia i Registre del Càncer. Institut Català d'Oncologia, Barcelona, Espanha) and Dr. Susana Sans (programaCRONICAT, Pavelló del Convent 2, Hospital de San Pau. Barcelona. Espanha). This study was funded by FUNDUNESP(Fundação para o DesenvolvimentodaUNESP), proc. $n^{\circ}$ 013/92-DFP/F/CBS.

\section{References}

1. Kalache A, Veras RP, Ramos LR. O envelhecimento da população mundial. Um desafio novo. Rev Saúde Pública, 1987; 21: 200-10.

2. Soares CA. Envelhecimento da população paulista: uma análise do período 1970-91. Conjunt Demogr 1994; 29: 17-31.

3. Hernandez Yero A, Diaz O, Rodrigues Garcia J. Valor del certificado de defuncion el la diabetes mellitus. Rev Cubana Med 1987; 26: 144-9.

4. Kirschbaum A, Cornejo Arias E. Mortalidad del senescente en Chile. Cuad Med Soc 1988; 29: 134-8.

5. Camargo ABM. De que morrem os idosos em São Paulo? Conjunt Demogr 1993; 23: 21-42.

6. Fernandes JG. Epidemiologia das doenças cerebrovasculares/Epidemiology of cerebrovascular diseases. Rev Assoc Med Rio Gd do Sul 1989; 33: 353-61.

7. Ramos LR, et al. Doenças cardiovasculares no idoso: implicações clínicas dos dados epidemiológicos. Rev Soc Cardiol Estado de São Paulo 1991; 1: 6-12.

8. Yazaki LM, Saad PM. Mortalidade da população idosa. In: Fundação Sistema Estadual de Análise de Dados. O idoso na Grande São Paulo. São Paulo: Realidade Paulista, 1990: 125-9.

9. Chor D, Duchiade MP, Jourdan AMF. Diferencial de mortalidade em homens e mulheres em localidade da região sudeste, Brasil - 1960, 1970e 1980. Rev Saúde Pública, 1992; 26: 246-55.

10. Kromhout D, et al. Serum cholesterol and 25-Year incidence of and mortality from myocardial infarction an cancer. Arch Intern Med 1988; 148: 1051-5.

11. Pekkanen $\mathrm{J}$, et al. Ten-year mortality from cardiovascular disease in relation to cholesterol level among men with and without preexisting cardiovascular disease. N Engl J Med 1990; 322: 1700-7.

12. Rosolova H, Simon J, Sefrna F. Impact of cardiovascular risk factors on morbidity and mortality in Czech middle-aged men: pilsen longitudinal study. Cardiology 1994; 85: 61-8.

13. Andersson OK, Almgren T, Persson BS, Samuelsson O, Hednen T, Wilhelmsen L. Survival in treated hypertension: follow up study after two decades. Br Med J 1998; 317: 167-71.

14. Boshuizen HC, Izaks G, Van Buuren S, Ligthart GJ. Blood pressure and mortality in elderly people aged 85 and older: community based study. Br Med J 1998; 316 : 1780-4.

15. Glynn RJ, et al. Evidence for a positive linear relation between blood pressure and mortality in elderly people. Lancet $1995 ; 345$ : 825-9.

16. Menotti A, Seccareccia SG, Giuli B. The predictive role of systolic, diastolic and mean blood pressures on cardiovascular and all causes of death. J Hypertens 1989; 7: 595-9.

17. Staessen J, et al. Relation between mortality and treated blood pressure in elderly patients with hypertension: report of the European Working Party on High Blood Pressure in the elderly. Br Med J 1989; 298: 1552-6.

18. Taylor JO, et al. Blood pressure and mortality risk in the elderly. Am J Epidemiol 1991; 134: 489-501.

19. Rissanen A, et al. Weight and mortality in finnish men. J Clin Epidemiol 1989; 42: 81-9.

20. Butler WJ, et al. Mortality from coronary heart disease in the Tecumseh Study. Am J Epidemiol 1985; 121: 541-7.

21. Vagero D, Norell SE. Mortality and social class in Sweden - Exploring a new epidemiological tool. Scand J Soc Med 1989; 17: 49-58.

22. Mendes-de-Leon CF, et al. Risk of mortality and coronary heart disease by marital status in middle-aged men in The Netherlands. Int J Epidemiol 1992; 21: 460-6.

23. Olsen O. Impact of social network on cardiovascular mortality in middle aged Danish men. J Epidemiol Community Health 1993; 47: 174-80.

24. Carandina L, Sanches O, Carvalheiro JR. Análise das condições de saúde e de vida da população urbana de Botucatu (SP). I. Descrição do plano amostral e avaliação da amostra. Rev Saúde Pública 1986; 20: 465-74.

25. Kaplan EL, Meier P. Nonparametric estimation from incomplete observation. J Am Statistical Association 1958; 53: 457-81.

26. OMS. Manual da Classificação Estatística Internacional de Doenças, Lesões e Causas de Óbito: classificação internacional das doenças. São Paulo, 1975; 1: 815.

27. Cox DR. Regression models and life tables (with discussion). J Royal Statistical Society, Ano??? B; 43: 187-220.

28. Collet D. Modelling survival data in medical research. London: Champman \& Hall, 1994: 347p 